\title{
EVALUATION OF THERMODYNAMIC LEARNING PROGRAM
}

\section{(Evaluasi Program Perkuliahan Termodinamika)}

\author{
Arini Rosa Sinensis ${ }^{1 *}$. Thoha Firdaus ${ }^{2}$ \\ ${ }^{1,2}$ Kandidat Doktor Universitas Pendidikan Indonesia \\ 1,2Pendidikan Fisika STKIP Nurul Huda \\ *arinirosa@student.upi.edu
}

\begin{abstract}
This paper describes the evaluation of the program of Learning thermodynamics developed based on Open Inquiry for physics teacher prospective students. The CIPP model is used as a reference for Program Evaluation. Context evaluation is designed to provide information related to thermodynamic lecture issues including teaching materials, assessment used, media, laboratory activities and others. Input evaluation is designed to provide information about the profiles of pre-program lecturers and lecturers based on Open Inquiry. Process evaluation, called monitoring, is designed to reveal the strengths and weaknesses of program implementation. Product evaluation (output and outcome) is designed to assess program success and program sustainability. The data collected are qualitative and quantitative data (Mixed methode). Data collection techniques used questionnaires, observation sheets, interviews, mastery tests of thermodynamic concepts and reflective thinking skills. Data analysis and program evaluation procedures are described in this paper.
\end{abstract}

Key words: Thermodynamics, Open Inquiry, Program Evaluation , CIPP Model

\begin{abstract}
ABSTRAK
Makalah ini menjelaskan tentang evaluasi program perkuliahan termodinamika yang dikembangkan berbasis Open Inquiry bagi mahasiswa calon guru fisika. Model CIPP digunakan sebagai referensi untuk Evaluasi Program. Evaluasi konteks dirancang untuk memberikan informasi yang berkaitan dengan masalah perkuliahan termodinamika meliputi bahan ajar, assesmen yang digunakan, media, aktivitas kegiatan laboratorium dan sebagainya. Evaluasi input dirancang untuk memberikan informasi mengenai profil mahasiswa dan dosen pra program perkuliahan termodinamika berbasis Open Inquiry. Evaluasi proses, yang disebut monitoring, dirancang untuk mengungkap kekuatan dan kelemahan pelaksanaan program. Evaluasi produk (keluaran dan hasil) dirancang untuk menilai keberhasilan program dan keberlanjutan program. Data yang dikumpulkan merupakan data kualitatif dan kuantitatif (Mixed methode). Teknik pengumpulan data menggunakan angket, lembar observasi, wawancara, tes penguasaan konsep termodinamika dan kemampuan berpikir reflektif. Analisis data dan prosedur evaluasi program dijelaskan dalam makalah ini.
\end{abstract}

Kata Kunci: Termodinamika, Open Inquiry, Evaluasi program, Model CIPP 


\section{PENDAHULUAN}

Kerangka Kualifikasi Nasional Indonesia (KKNI) didasarkan pada asas konsistensi, dimana harus ada kesesuaian antara University learning outcome, program of study learning outcome dan course learning outcome, sehingga efek dari pengembangan kurikulum dapat terasa sampai pada peningkatan mutu pembelajaran. Hal tersebut mendorong dosen untuk terus meningkatkan kualitas perkuliahan dengan mempertimbangkan kepada komponenkomponen tersebut. Fokus terbaru dari ilmu pendidikan telah membangun keterampilan dan praktik ilmiah, diluar dari konten. Holmes dan Wieman (2016) kegiatan di laboratorium adalah platform utama di mana peserta didik dapat mengalami praktik-praktik dengan cara "hands-on atau mind-on". Calon guru Fisika harus mampu merancang eksperimen fisika, pemahaman konsep, memiliki keterampilan ilmiah dan melaksanakannya dengan cara yang benar serta mampu menerapkan ilmu sains dengan menggunakan teknologi dengan memperhatikan lingkungan sehari-hari. Melalui sebuah penyelidikan (Inquiry) dalam pemecahan masalah, mahasiswa dapat menjadi terampil dalam (mengidentifikasi, memilih pengetahuan yang relevan, mengorganisasikan keterampilan yang sudah dimiliki, membuat rencana, dan membuat generalisasi).

Menurut Wenning (2010:12) pembelajaran inkuiri merupakan kegiatan siswa dimana mereka mengembangkan pengetahuan dan pemahaman tentang ide-ide ilmiah, serta pemahaman tentang bagaimana ilmuwan mempelajari alam. Standar untuk menentukan kemampuan mahasiswa diperlukan penyelidikan ilmiah, mengidentifikasi pertanyaan dengan panduan konsep ilmiah, desain dan kerja ilmiah, menggunakan teknologi untuk meningkatkan penyelidikan, merumuskan dan merevisi penjelasan ilmiah menggunakan logika dan bukti, mengenali dan menganalisis, serta mempertahankan ide ilmiah. Meskipun demikian, Standar tersebut hanya memberikan gambaran sedikit tentang bagaimana proses penyelidikan yang akan digunakan atau diajarkan. Jenis Open Inquiry sangat cocok digunakan pada level mahasiswa, Bruck,dkk (2008) menyatakan bahwa dimana dosen menyiapkan masalah dan latar belakang, tetapi prosedur,desain, metodologi serta analisis dan kesimpulan mahasiswa yang membuatnya. Dosen membuat pertanyaan baru dan memutuskan mana pertanyaan yang diuji kemudian mahasiswa memilih pertanyaan untuk diselidiki, membuat rencana (termasuk cara untuk memperoleh data), dan membuat prediksi tentang apa yang mahasiswa ketahui sebelumnya. 
Termodinamika adalah bagian dari cabang Fisika Termofisika (Thermal Physics) yang mempelajari hubungan antara energi dan kerja dari suatu sistem. Termodinamika hanya mempelajari besaran-besaran yang berskala besar (makroskopis) dari sistem yang dapat diamati dan diukur dalam eksperimen. Termodinamika merupakan ilmu yang berlandaskan pada hasil-hasil eksperimen. Perkuliahan termodinamika dengan beban 3 sks yang harus ditempuh oleh mahasiswa pada semester 3. Hasil temuan lapangan di STKIP Nurul Huda ditemukan bahwa penguasaan konsep dasar termodinamika rendah dari hasil tes, selain itu penerapan perkuliahan termodinamika yang belum meningkatkan scientific Process skill dan berdasarkan hasil wawancara mahasiswa menyatakan bahwa mata kuliah ini sulit dipelajari karenasalah satunya adalah banyak penerapan fisika matematika, oleh karena itu melalui sebuah program perkuliahan termodinamika berbasis open inquiry dengan eksplorasi epistemologi dapat menjadi solusi untuk pemecahan masalah, penguasaan konsep, meningkatkan keterampilan praktik ilmiah, kolaborasi dan dengan keterampilan tersebut diharapkan menghasilkan peserta didik yang independen dan analitis serta menghasilkan lulusan yang reflektif dan produktif (Vaiyavutjamai, et al.2012).

Learning outcome dalam perkuliahan termodinamika berbasis open inquiry harus sesuai dengan KKNI sebagai berikut 1) Menguasai konsep teoritis term bidang pengetahuan termodinamika dan keterampilan tertentu secara umum dan konsep teoritis bagian khusus dalam bidang pengetahuan dan keterampilan tersebut secara mendalam. 2)Menguasai prinsipprinsip dan teori-teori pengelolaan dan keselamatan kerja/belajar di laboratorium maupun di luar laboratorium. 3) Memahami potensi, karakteristik dan pengembangan karir peserta didik. 4) Menguasai teori/model pembelajaran untuk merancang, melaksanakan, dan mengevaluasi pembelajaran fisika (termodinamika) sesuai perkembangan peserta didik. 5) Memahami struktur (termasuk hubungan fungsional antar konsep) ilmu Fisika dan ilmu-ilmu lain yang terkait. 6)Mampu bernalar secara kualitatif maupun kuantitatif tentang proses dan hukum fisika. 7) Memahami konsep-konsep, hukum-hukum, dan teori-teori fisika serta penerapannya secara fleksibel. Oleh karena perlu inovasi pengembangan program perkuliahan Termodinamika yang lebih menekankan pada pemecahan masalah, keterlibatan aktif mahasiswa, pengembangan keterampilan ilmiah, melalui program perkuliahan berbasis Open inquiry.

Evaluasi progam penting dilaksanakan pertama evaluasi dalam perencanaan yang di dalamnya termasuk dalam input bagaimana memilih strategi tertentu untuk melaksanakan dan menyelesaikan masalah dan membuat keputusan tentang bagaimana penerapannya. Kedua 
evaluasi dalam proses di mana dan apakah program yang sedang dilaksanakan sesuai rencana, dan apakah ada perubahan apa yang telah dilakukan, selain itu mengetahui hambatan apa saja yang dialami tenaga pengajar dan mahasiswa dalam melaksanakan program. Ketiga evaluasi dalam hasil, hal ini untuk mengetahui setelah diadakannya program perkuliahan termodinamika berbasis Open Inquiry dampak apa yang mempengaruhi mahasiswa calon guru fisika, dan apakah program tersebut berkelanjutan. Oleh karena itu dalam makalah ini akan dijelaskan tentang prosedur evaluasi program perkuliahan termodinamika.

\section{TUJUAN IMPLEMENTASI PROGRAM}

Tujuan program perkuliahan termodinamika adalah meningkatkan proses dan capaian hasil pembelajaran antara lain: (1) Penerapan pembelajaran hands-on and Mind -on yang memberikan banyak kesempatan kepada mahasiswa untuk mengkonstruksi pengetahuan berdasarkan pengalaman kongkrit; (2) Penerapan pembelajaran collaborative problem solving skills yang memberikan kesempatan kepada mahasiswa untuk berpikir kritis, menyeimbangkan argumen, menjadi terbuka untuk menerima kritik alternatif konstruktif, menumbuhkan dan menghargai pendapat kelompok lain dan kemampuan dalam mengambil keputusan; (3) Peningkatan kemampuan fisika matematika dalam termodinamika dengan menggunakan metode derivative games (epistemik kognisi) serta (4) Kemampuan berpikir reflektif mahasiswa dalam pemecahan masalah.

\section{TUJUAN EVALUASI PROGRAM}

Tujuan evaluasi program perkuliahan termodinamika adalah untuk merumuskan program perkuliahan yang inovatif. Secara khusus evaluasi program ini bertujuan untuk ; 1) Memperoleh kekuatan dan kelemahan program perkuliahan termodinamika yang dilaksanakan, 2) Merumuskan program perkuliahan termodinamika dengan inovasi baru sesuai dengan kebutuhan saat, 3) Mengetahui kesesuaian pelaksanaan perkuliahan dengan program perkuliahan termodinamika yang baru. 3) Mengetahui tanggapan mahasiswa terhadap pelaksanaan program perkuliahan. 4) Menganalisis kendala-kendala yang dialami dalam implementasi program perkuliahan termodinamika.

\section{MODEL, DESAIN DAN METODE EVALUASI PROGRAM}

Model evaluasi program yang digunakan pada evaluasi program ini adalah model CIPP (Context, Input, Process, Product). Alasan pemilihan model evaluasi ini dikarenakan program ini masih dalam perumusan dan perancangan, maka model ini sesuai dengan 
karakteristik model CIPP yang merumuskan program berdasarkan analisis konteks dan input. Model evaluasi CIPP meakukan evaluasi pada setiap sub-komponen program, meliputi evaluasi konteks, input, proses dan produk. Desain evaluasi yang digunakan adalah time series design. Design ini mengacu pada pengukuran secara berkala terhadap kemampuan mahasiswa. Metode yang digunakan adalah mixed methods yang mendorong evaluator untuk menggunakan berbagai sumber (multiple source) dan metode, baik itu metode kuantitatif maupun metode kualitatif (Fitzpatrick, Sanders \& Worthen, 2012).

Evaluasi konteks merupakan need assessment kebutuhan dosen dalam meningkatan keterampilan dan penguasaan konten mahasiswa calon guru fisika. Sasaran evaluasi mencakup permasalahan yang dihadapi mahasiswa yaitu kesulitan dalam penguasaan konsep termodinamika, kelemahan yang ada pada aspek pembelajaran, pemahamanan matematis, media dan alat pembelajaran, aktivitas laboratorium (keterampilan kinerja ilmiah), bahan ajar, asesmen pelajaran, dan sebagainya. Dari hasil evaluasi konteks dapat disimpulkan misi utama program perkuliahan termodinamika berbasis Open inquiry, serta substansi inovasi yang perlu menjadi muatan kegiatan tersebut, khususnya aspek-aspek kompetensi perlu dikembangkan melalui program perkuliahan termodinamika melalui kegiatan Open inquiry dengan eksplorasi epistemologi dan collaborative problem solving skills.

Evaluasi input berfokus pada pengumpulan informasi input yang penting seperti profil mahasiswa (antara lain kapasitas belajar, tingkat motivasi dan prestasi belajar), profil dosen (antara lain latar belakang pendidikan dan pengalaman mengajar, keterampilan mengajar dan pemahaman konten termodinamika, sikap terhadap suatu inovasi, kegiatan penelitian dan pengabdian), serta fasilitas belajar yang tersedia di kampus dan dukungan ketua program studi Pendidikan Fisika dan ketersediaan fasilitas dan sumber daya (resource) program perkuliahan termodinamika.

Evaluasi proses (dapat disebut monitoring) berkenaan dengan kajian seberapa jauh pelaksanaan operasional kegiatan perkuliahan termodinamika berbasis open inquiry berjalan secara efektif ke arah pengembangan keterampilan kinerja ilmiah, pemahaman konsep, epistemik kognisi, collaborative problem solving skills, dan kemampuan berpikir reflektif, mahasiswa calon guru yang diharapkan. Evaluasi proses bersifat sebagai evaluasi formatif, sehingga temuan-temuan dari evaluasi proses perlu segera disampaikan sebagai umpan balik kepada pihak-pihak terkait, khususnya mahasiswa calon guru fisika, dosen, ketua program studi dan pembimbing akademik.

Evaluasi produk ini adalah kegiatan mengumpulkan berbagai informasi mengenai hasil pelaksanaan program, membandingkannya dengan standar dan mengambil keputusan 
mengenai komponen tujuan-tujuan program. Evaluasi produk dalam evaluasi program ini mencakup evaluasi keluaran (output) dan dampak (impact). Evaluasi output berbeda dengan evaluasi impact, evaluasi output terarah pada hasil langsung program, baik perubahan indikator-indikator keberhasilan program, kemampuan-kemampuan (pemahaman konsep, matematis, epistemik kognisi) dan kinerja mahasiswa setelah implementasi program (Kinerja ilmiah, collaborative problem solving skills), baik yang terkait pada kualitas pembelajaran, motivasi belajar, maupun hasil belajar berdasarkan komparasi antara keadaan sebelum dan sesudah program perkuliahan termodinamika berbasis open inquiry dilaksanakan. Evaluasi impact (dampak) lebih bersifat monitoring terhadap keberlanjutan (sustainability) aktivitas perkuliahan termodinamika pasca pelaksanaan program. Hal ini dilakukan untuk melihat sejauh mana hasil program perkuliahan dapat diterapkan dan menghasilkan lulusan yang tidak hanya paham konsep akan tetapi memiliki keterampilan kerja ilmiah dan kemampuan berpikir reflektif.

\section{STRUKTUR DATA DAN INSTRUMEN}

Data merupakan bahan baku untuk proses evaluasi program. Data yang diperlukan tergolong ke dalam dua kelompok, yakni data kuantitatif dan data kualitatif. Sementara itu instrumen dikembangkan untuk mengungkap data-data yang diperlukan, baik data kuantitatif maupun data kualitatif. Struktur data dan model instrumentasi yang dikembangkan untuk implementasi keseluruhan proses evaluasi program dapat dilihat pada Tabel 1:

Tabel 1 Struktur Data dan Instrumen Evaluasi Program

\begin{tabular}{|c|c|c|c|c|c|c|}
\hline No & Aspek & Fokus & Jenis Informasi & Metode & $\begin{array}{c}\text { Sumber } \\
\text { Data }\end{array}$ & Instrumen \\
\hline \multirow[t]{2}{*}{1} & \multirow[t]{2}{*}{$\begin{array}{l}\text { Evaluasi } \\
\text { Konteks }\end{array}$} & $\begin{array}{l}\text { Learning } \\
\text { Outcome } \\
\text { Program } \\
\text { Studi }\end{array}$ & $\begin{array}{l}\text { Deskripsi Learning } \\
\text { outcome Program } \\
\text { Studi Pendidikan } \\
\text { Fisika }\end{array}$ & $\begin{array}{l}\text { Analisis } \\
\text { dokumen }\end{array}$ & $\begin{array}{l}\text { Ketua } \\
\text { Program } \\
\text { Studi }\end{array}$ & $\begin{array}{l}\text { Pedoman } \\
\text { observasi }\end{array}$ \\
\hline & & $\begin{array}{l}\text { Perkuliahan } \\
\text { termodinamik } \\
\text { a }\end{array}$ & $\begin{array}{l}\text { - SAP } \\
\text { - Silabus } \\
\text { - Assesmen } \\
\text { - Lembar kegiatan } \\
\text { mahasiswa } \\
\text { - Proses } \\
\text { perkuliahan } \\
\text { - Bahan Ajar } \\
\text { - Media penunjang } \\
\text { perkuliahan } \\
\text { - Laboratorium } \\
\text { - Lingkungan }\end{array}$ & $\begin{array}{l}\text { Analisis } \\
\text { Dokumen dan } \\
\text { Observasi }\end{array}$ & $\begin{array}{l}\text { Dosen, } \\
\text { mahasiswa }\end{array}$ & $\begin{array}{l}\text { Pedoman } \\
\text { Observasi }\end{array}$ \\
\hline
\end{tabular}


belajar yang

mendukung

perkuliahan

\begin{tabular}{|c|c|c|c|c|c|c|}
\hline \multirow[t]{2}{*}{2} & \multirow[t]{2}{*}{$\begin{array}{l}\text { Evaluasi } \\
\text { input }\end{array}$} & $\begin{array}{l}\text { Profil } \\
\text { Mahasiswa } \\
\text { pra program } \\
\text { perkuliahan } \\
\text { berbasis open } \\
\text { inquiry }\end{array}$ & $\begin{array}{l}\text { - Penguasaan } \\
\text { konsep } \\
\text { termodinamika } \\
\text { - Motivasi belajar } \\
\text { - Prestasi belajar }\end{array}$ & $\begin{array}{l}\text { Analisis } \\
\text { Dokumen, } \\
\text { intrumen tes } \\
\text { dan } \\
\text { wawancara }\end{array}$ & Mahasiswa & $\begin{array}{l}\text { Tes Standar } \\
\text { dan } \\
\text { Pedoman } \\
\text { interviu } \\
\text { Kuesioner }\end{array}$ \\
\hline & & Profil dosen & $\begin{array}{l}\text { - Latar belakang } \\
\text { pendidikan } \\
\text { - Pengalaman } \\
\text { mengajar } \\
\text { - Kemampuan } \\
\text { menyusun } \\
\text { Silabus dan SAP } \\
\text { - Profil gender dan } \\
\text { usia } \\
\text { - Penelitian dan } \\
\text { pengabdian } \\
\text { kepada } \\
\text { masayarakat } \\
\end{array}$ & $\begin{array}{l}\text { Observasi, } \\
\text { revieu } \\
\text { dokumen, } \\
\text { interviu, } \\
\text { angket profil } \\
\text { dosen }\end{array}$ & Dosen & $\begin{array}{l}\text { Pedoman } \\
\text { interviu dan } \\
\text { kuisoner }\end{array}$ \\
\hline \multirow[t]{2}{*}{3} & \multirow[t]{2}{*}{$\begin{array}{l}\text { Evaluasi } \\
\text { proses }\end{array}$} & $\begin{array}{l}\text { Perancangan } \\
\text { program } \\
\text { perkuliahan } \\
\text { termodinamik } \\
\text { a }\end{array}$ & $\begin{array}{l}\text { - SAP dan Silabus } \\
\text { - Pengembangan } \\
\text { Bahan ajar } \\
\text { - Pengembangan } \\
\text { Lembar Kegiatan } \\
\text { mahasiswa } \\
\text { - Pengembangan } \\
\text { media } \\
\text { - Pengembangan } \\
\text { instrumen tes } \\
\text { - Pengembangan } \\
\text { Asesmen }\end{array}$ & $\begin{array}{l}\text { Reviu } \\
\text { dokumen, } \\
\text { Observasi dan } \\
\text { interviu }\end{array}$ & Dosen & $\begin{array}{l}\text { Pedoman } \\
\text { observasi } \\
\text { dan interviu }\end{array}$ \\
\hline & & $\begin{array}{l}\text { Implementasi } \\
\text { program }\end{array}$ & $\begin{array}{l}\text { - Proses } \\
\text { Perkuliahan } \\
\text { - Keefektifan } \\
\text { program } \\
\text { perkuliahan } \\
\text { - Refleksi } \\
\text { Program } \\
\text { perkuliahan } \\
\text { termodinamika } \\
\text { - Tanggapan } \\
\text { observer } \\
\text { - Sikap mahasiswa } \\
\text { - Tanggapan } \\
\text { Kaprodi }\end{array}$ & $\begin{array}{l}\text { Observasi, } \\
\text { Interviu, } \\
\text { catatan } \\
\text { lapangan }\end{array}$ & $\begin{array}{l}\text { Dosen, } \\
\text { mahasiswa } \\
\text { dan } \\
\text { observer }\end{array}$ & $\begin{array}{l}\text { Pedoman } \\
\text { observasi } \\
\text { kegiatan; } \\
\text { Kuesioner; } \\
\text { Pedoman } \\
\text { interviu. }\end{array}$ \\
\hline 4 & $\begin{array}{l}\text { Evaluasi } \\
\text { Keluaran } \\
\text { (Output) }\end{array}$ & $\begin{array}{l}\text { Kemampuan } \\
\text { Mahasiswa }\end{array}$ & $\begin{array}{l}\text { - Penguasaan } \\
\text { konsep } \\
\text { termodinamika } \\
\text { - Kinerja ilmiah } \\
\text { - Epistemic }\end{array}$ & $\begin{array}{l}\text { Tes } \\
\text { penguasaan } \\
\text { konsep } \\
\text { assesmen }\end{array}$ & Mahasiswa & $\begin{array}{l}\text { Pedoman } \\
\text { observasi } \\
\text { dan } \\
\text { instrumen }\end{array}$ \\
\hline
\end{tabular}


- Kolaboratif problem solving

Tes

- Berpikir reflektif kemampuan berpikir reflektif

Tes epistemic kognisi

\begin{tabular}{|c|c|c|c|}
\hline $\begin{array}{l}\text { Tanggapan } \\
\text { Mahasiswa }\end{array}$ & $\begin{array}{l}\text { Persepsi mahasiswa } \\
\text { terhadap program } \\
\text { perkuliahan } \\
\text { termodinamika }\end{array}$ & $\begin{array}{l}\text { Angket } \\
\text { persepsi } \\
\text { mahasiswa } \\
\text { terhadap } \\
\text { program } \\
\text { perkuliahan } \\
\text { termodinamik } \\
\text { a berbasis } \\
\text { Open inquiry }\end{array}$ & Mahasiswa \\
\hline
\end{tabular}

\begin{tabular}{|c|c|c|c|}
\hline $\begin{array}{l}\text { Tanggapan } \\
\text { dosen }\end{array}$ & $\begin{array}{l}\text { Persepsi dosen } \\
\text { terhadap } \\
\text { keunggulan dan } \\
\text { kelemahan program }\end{array}$ & $\begin{array}{l}\text { Angket } \\
\text { persepsi dosen } \\
\text { terhadap } \\
\text { keunggulan } \\
\text { dan } \\
\text { kelemahan } \\
\text { program }\end{array}$ & Dosen \\
\hline
\end{tabular}

\begin{tabular}{|c|c|c|c|c|c|c|}
\hline 5 & $\begin{array}{l}\text { Evaluasi } \\
\text { dampak } \\
\text { (Impact) }\end{array}$ & $\begin{array}{l}\text { Keberlanjutan } \\
\text { Program }\end{array}$ & $\begin{array}{l}\text { Keberlanjutan } \\
\text { program } \\
\text { perkuliahan } \\
\text { termodinamika } \\
\text { berbasis Open } \\
\text { inquiry }\end{array}$ & $\begin{array}{l}\text { Interviu, } \\
\text { analisis } \\
\text { dokumen dan } \\
\text { observasi }\end{array}$ & $\begin{array}{l}\text { Dosen, } \\
\text { SAP dan } \\
\text { silabus }\end{array}$ & $\begin{array}{l}\text { Pedoman } \\
\text { analisis } \\
\text { keterlaksana } \\
\text { an program; } \\
\text { Tes Standar, } \\
\text { Pedoman } \\
\text { interviu; } \\
\text { Kuesioner; }\end{array}$ \\
\hline & & $\begin{array}{l}\text { Kompetensi } \\
\text { mahasiswa }\end{array}$ & $\begin{array}{l}\text { - Penguasaan } \\
\text { konsep } \\
\text { termodinamika } \\
\text { - Kinerja ilmiah } \\
\text { - Epistemic } \\
\text { kognisi } \\
\text { - Kolaboratif } \\
\text { problem solving } \\
\text { - Berpikir reflektif }\end{array}$ & $\begin{array}{l}\text { Tes } \\
\text { penguasaan } \\
\text { konsep } \\
\text { assesmen } \\
\text { kinerja } \\
\text { Tes } \\
\text { kemampuan } \\
\text { berpikir } \\
\text { reflektif } \\
\text { Tes epistemic } \\
\text { kognisi }\end{array}$ & Mahasiswa & $\begin{array}{l}\text { Pedoman } \\
\text { observasi } \\
\text { dan } \\
\text { instrumen } \\
\text { tes }\end{array}$ \\
\hline & & $\begin{array}{l}\text { Profil } \\
\text { Lulusan } \\
\text { pendidikan }\end{array}$ & $\begin{array}{l}\text { - Penguasaan } \\
\text { konsep } \\
\text { termodinamika } \\
\text { - Kinerja ilmiah } \\
\text { - Epistemic }\end{array}$ & $\begin{array}{l}\text { Observasi dan } \\
\text { interviu }\end{array}$ & Mahasiswa & $\begin{array}{l}\text { Pedoman } \\
\text { observasi } \\
\text { dan interviu }\end{array}$ \\
\hline
\end{tabular}




\begin{tabular}{ll}
\hline fisika & kognisi \\
& - Kolaboratif \\
& problem solving \\
& - Berpikir reflektif
\end{tabular}

ANALISIS DATA

Analisis Data Kuantitatif dalam evaluasi program ini diperoleh tiga macam data yaitu: angket, observasi, peningkatan hasil belajar ( $N$-gain ternormalisasi) dan data hasil tes yang dianalisis dan dievaluasi. Pengujian kesahihan tes meliputi validitas butir soal, reliabilitas, tingkat kesukaran, dan daya pembeda.

Analisis Data Kualitatif data awal yang diperoleh kemudian dianalisis dengan cara ditrankripsi, dipilah dan disusun berdasarkan jenis sumber informasinya. 1) Seluruh data direfleksikan maknanya secara keseluruhan kemudian disimpulkan dan mencatat gagasangagasan dari hasil pemaknaan. 2) instrumen lembar observasi, pedoman wawancara dan analisis dokumen. Data tersebut kemudian dianalisis secara cermat, kemudian peneliti menginterpretasikan analisisnya dan menarik kesimpulan yang berisikan intisari dari seluruh rangkaian kegiatan penelitian dan membuat rekomendasinya. Data kualitatif tersebut di triangulasi berdasarkan perolehan sumber data yang satu dengan yang lainnya. Triangulasi data berarti membandingkan dan mengecek balik derajat kepercayaan suatu informasi yang diperoleh melalui waktu dan alat yang berbeda dalam metode kualitatif (Moleong, 1990: 178). Triangulasi data dari penelitian ini diperoleh dengan melakukan cross-check informasi antara informan yang satu dengan informan yang lain. Adapun dari beberapa macam teknik triangulasi, maka pada penelitian ini yang akan digunakan adalah teknik triangulasi sumber. Triangulasi sumber adalah teknik yang digunakan dengan cara membandingkan dan mengecek balik derajat kepercayaan suatu informasi yang diperoleh melalui waktu dan alat yang berbeda dalam metode kualitatif. Proses triangulasi sumber tersebut, maka pada evaluasi ini akan digunakan cara dengan membandingkan (1) hasil wawancara dengan hasil pengamatan, (2) perspektif mahasiswa dan dosen tentang pelaksanaan program.

\section{ORGANISASI IMPLEMENTASI EVALUASI PROGRAM}

Perencanaan, implementasi dan penyusunan laporan evaluasi program perkuliahan termodinamika dilaksanakan oleh evaluator (peneliti). Evaluator bekerja sebelum program perkuliahan dilaksanakan, yakni untuk merencanakan (termasuk menyusun instrumen) dan termasuk pengumpulan data, analisis data dan penyusunan laporan). Hasil tersebut terdiri atas dua kategori data, yakni: (1) Data kondisi-kondisi pra-program perkuliahan termodinamika berbasis open inquiry yang akan digunakan untuk dibandingkan dengan data hasil akhir 
setelah dilaksanakan program untuk tujuan evaluasi sumatif efektivitas program perkuliahan termodinamika berbasis Open Inquiry ; dan (2) Data yang menggambarkan kondisi mahasiswa, dosen, perangkat pembelajaran, sarana penunjang perkuliahan yang digunakan untuk diantisipasi dalam perencanaan dan implementasi program.

Tugas Evaluator (Peneliti) adalah melakukan evaluasi program terhadap pelaksanaan program perkuliahan termodinamika . Evaluasi dilakukan terhadap keseluruhan tahap-tahap pelaksanaan program perkuliahan termodinamika. Agar tercapai konsistensi dalam melakukan pengumulan dan analisis data, serta pelaporan temuan. Penyusunan laporan disusun berdasarkan setiap tahapan program perkuliahan termodinamika berbasis open inquiry. Evaluator menghasilkan laporan dan disampaikan kepada pihak-pihak terkait (dosen fisika dan kaprodi pendidikan fisika). Selanjutnya digunakan untuk dalam pembuatan keputusan dalam perencanaan selanjutnya. Apabila terdapat temuan yang penting maka perlu ditindaklanjuti. Evaluator melakukan evaluasi pada tahap akhir yaitu dilakukan menjelang akhir program perkuliahan dilaksanakan, dengan tujuan untuk memotret kondisi akhir program dan membandingkannya dengan kondisi pra-program perkuliahan termodinamika berbasis Open Inquiry.

\section{PENUTUP}

Pentingnya evaluasi program perkuliahan termodinamika adalah sebagai bahan rekomendasi untuk perbaikan program perkuliahan karena evaluasi program akan menghasilkan inovasi baru dalam pengembangan program perkuliahan dan memberikan masukan kepada pihak terkait sejauhmana keefektifan program dilaksanakan dalam memperbaiki kelemahan-kelemahan program perkulihan sebelumnya, sehingga program inovasi yang baru dapat berjalan dengan baik. Evaluasi program dalam makalah ini dikembangkan untuk mengeksplorasi sejauhmana program yang dilaksanakan telah valid dan cocok dengan kebutuhan saat ini yaitu berdasarkan kerangka kualifikasi dalam KKNI, capaian pembelajaran yaitu kemampuan mahasiswa yang diperoleh melalui internalisasi pengetahuan, keterampilan, kompetensi, dengan unsur yaitu sikap dan tata nilai, kemampuan kerja,dan tanggung jawab harus dibekali dalam pengembangan program perkuliahan. Evaluasi Program perkuliahan termodinamika ini tidak tepat juga jika dipandang sebagai hasil yang final, sebab akan secara berkelanjutan direvisi dan ditingkatkan efektivitasnya sesuai dengan pengembangan keilmuan pendidikan.

\section{DAFTAR PUSTAKA}


Buck, L. B., Bretz, S. L., \& Towns, M. H. (2008)." Characterizing the level of inquiry in the undergraduate laboratory". Journal of College Science Teaching, 38(1), 52.

Creswell, JW and Clark, P.V. (2007). "Designing and Conducting Mixed Methods Research". London : sage publication

Fitzpatrick, J. L., Worthen, B. R., dan Sander, J. R. (2012). "Program Evaluation Alternative Approaches and Partical Guidlines". New Jersey: Pearson.

Holmes, N. G., \& Wieman, C. E. (2016). "Examining and contrasting the cognitive activities engaged in undergraduate research experiences and lab courses". Physical Review Physics Education Research, 12(2), 020103.

Moleong, J. Lexi, (1990). "Metode Penelitian Kualitatif “Bandung : PT Remaja Rosdakarya

Vaiyavutjamai, P., Charoenchaia, S., Ponmanee, S., Danpakdee, A., Chotivachira, B., Warotamawit, V., ... \& Sitthiwong, W. (2012). "Collaborative action research to promote reflective thinking among higher education students". Procedia-Social and Behavioral Sciences, 47, 739-744.

Wenning, C. J. (2010). "Levels of inquiry: Using inquiry spectrum learning sequences to teach science". Journal of Physics Teacher education online, 5(4), 11-19.

Zwickl, B. M., Hu, D., Finkelstein, N., \& Lewandowski, H. J. (2015). "Model-based reasoning in the physics laboratory: Framework and initial results". Physical Review Special Topics-Physics Education Research, 11(2), 020113. 